\title{
Digital Technologies in Managing Food Industry Enterprises
}

\author{
Rozhdestvenskaya L.N. ${ }^{*}$ Rogova O.V. Cherednichenko L.Ye.
}

\author{
The Department of Food Production Technology Novosibirsk State Technical University, Novosibirsk, Russia \\ *Corresponding author. Email: rozhdestvenskaya@corp.nstu.ru
}

\begin{abstract}
Digital technologies, actively used in the food service organization, have been considered. Various approaches to classification and search of catering establishments in the Internet space have been analyzed. The inconsistency of criteria for assessment and ranking of restaurants has been established. Increasing the quality of analytical information required for making managerial decisions aimed at the achievement of the company strategic goals is possible based on the allocation of sources of information used for analysis; development and approval of the policy of access to record and analytical data contained in the systems; marging out factors that can impact the information received from record and analytical systems. It has been offered to create a search information system with strictly fixed criteria of catering establishments selection. Terms of reference for the offered information search system, that will allow carrying out the multi-factor filtering and assessment of catering establishments with regard of interests of various groups of users (consumers, business owners, catering establishment critics), was developed. It will help to greatly facilitate the operation of marketing services and to business owners, quality monitoring of the services provided, to facilitate the customer choice.
\end{abstract}

Keywords: classification, catering establishments, information technologies, stakeholders, social entrepreneurship, market possibilities

\section{INTRODUCTION}

The digitalization era stimulated the development of numerous information technologies that are now successfully applied both in the organization of management processes in catering establishments and in methods of goods and services promotion in this market segment. Digital technolgies, actively used in the food service organization can include the following.

- Computer Aided Design (CAD), Computer Aided Manufacturing (CAM) are used in the design of catering establishments. Are implemented, in particular, in AutoCAD, KOMPAS-3D, nanoCAD, SketchUp.

- Computer Aided Engineering (CAE) systems for automation of technical and regulatory and technical document circulation, product quality control. As a system for automation of development technical documents, such software applications as Master TTK and Mini kulinaria can be used.

- Supervisory Control And Data Acquisition (SCADA) and Manufacturing Execution System (MES) are used for managing production processes at large primary food processing companies and manufacturing food enterprises.

- Sales Force Automation (SFA) are used for automation of the delivery and itinerant trade system.

- $\quad$ Enterprise Resource Planning (ERP) are used for comprehensive management in a catering establishment. They are conditionally divided into automation systems:

- Back office (accounting and control of the company resources), e.g., R-keeper StoreHouse, iikoOffice, 1C:Predpriyatiye.Obshchepit.

- Front office (area operation automation), e.g., Traktir: Front-Office, R-keeper, Tillypad XL, 1C:Predpriyatiye 8. Restaurant, Bit. Appetite. Restaurant.

- Business Process Management (BPM) is used for production business process management, e.g., ELMA BPM, Bizagi BPM Suite.

- Customer Relationship Management (CRM) is used for sales and customer relationship management. Such applications as $1 \mathrm{C}$ : Sales and 
customer relationship management, TakoCRM, M-Bron can be used for this purpose.

The software development for assessing the competencies of the contact area employees can be also included into the innovations in the field of IT products in managing the activities of catering establishments. The study showed that the existing methods of assessment, such as KPI (Key Performance Indicator) and the 360 degree feedback method are difficult to be applied when assessing work of employees who are not managers (waiters). This application builds the employee's profile through his/her competency model, allowing to unite various criteria of the employee's work and forming his/her perfect profile created and stored in the application [1].

Catering establishments are interested in establishing longterm and stable relations with their customers to the higher extent in comparison with the other companies at the service market. The most actual in these terms is implementing software for customer relationship management (CRM), the goal of which is to help a restaurant owner to build the efficient permanent customer relationship (to retain customers), to optimize the work with current, and to attract the new ones. More and more often, the potential consumer, making a decision to visit some restaurant, is governed by the factor of easiness and pleasure of online communication with the restaurant team (availability of all information, fast order (table) reservation, accuracy in the products description ad the order fulfillment, politeness, attention to small detailsm etc.). With regard of all actuality and importance of the correct customer relationship building, developers of software for restaurant now offer for this purpose tens of new options of software and hardware sets, beside the well-known R-Keeper: Poster, SBIS Presto, NOMIA, Quick Resto, LeClick, and other CRM applications help to build a more efficient dialogue with the customer, to avoid omissions and errors and, as the result, to sell more. When clicking the customer's name, a convenient "active" card is opened containing the entire chronology of work with him/her - from the first call or visit to the current moment. Here, one can listen to the calls, view the order and visit history, create pattern-based documents, write an e-mail, text or messenger message, set and solve any other service task. When a customer makes a call, his/her card is opened automatically, enabling to greet this guest by a name immediately, even if previously, another manager was assigned for this person. The application will send the text message about the order status, will remind about the event time, send birthday wishes, accrue gift bonuses, etc. It is the coverage of all these important details that makes a customer more loyal and oriented at the choice of the certain catering establishment. Even the more considerable part is played by the introduction of the efficient CRM programs for companies working with consumers only in the delivery format, without their own trade areas. According to the e-resource of reviewing the food service market [2], one of the most prospective trends so far is the growth of popularity of "virtual restaurants" - restaurants without tables. Their only goal is the efficient food delivery to customers' houses and offices. For such catering establishments, establishing relations with consumers is possible only in the online space through search and their own webpages. Online services of food delivery from stores and restaurants now hold over one half of the global food tech market, and the main share in Russia [3]. American services DoorDash, Instacat, Uber Eats, and European services Deliveroo, Delivery Hero, Just Eat, Takeaway.com develop at this market. In Russia, the sphere of online food delivery has such competitors as Yandex and Mail.Ru Group, the owner of DeliveryClub, Zakazaka and Instamart.

CRM system should work in two directions. For a restaurant owner, it is the automation of the customer connection management process, the way of promoting goods and services. For a customer - a simple and easy way to receive all information about the establishment (menu, prices, promotions, etc.), book a table or order home delivery. However, most often, prior to investigating the menu and making orders, a customer has to select a restaurant matching his/her immediate wants, wishes, and possibilities.

Indirectly, such Internet portals asFlamp, Allcafe, TripAdvisor, giving some information about catering establishments, can be used for this. On these Internet portals, the company is searched based on the number of classification parameters. In the course of studies provided in [4, 5], a line of discrepancies during filtering the catering establishments on these Internet portals by various classification features was revealed. Being an active service market player, any catering establishment is subject to assessment not only by its guests but also the other participants of the entire system: state regulatory authorities, competitors, restaurant critics and other interested parties that don't have a possibility today to set the search of catering establishments by their inquiries and needs. It is caused by the absence of the strictly regulated classification and selection criteria. The creation of a search information system with the fixed criteria for selecting the catering establishment would allow business owners simplifying the work of marketing services and carrying out monitoring of the quality of services provided, and this would considerably simplify the consumer's choice.

\section{METHODS OF RESEARCH}

The logical frames of the study are represented by a presumption received on the basis of the use of the interdisciplinary framing analysis that one of the most complex aspects of creating the multi-branch cooperation in the field of establishment of the catering establishments market is the formation of trust between the interested parties and the development of the private sector ability to even out the income and the social responsibility. No catering establishment is able to function without taking into account the impact of the aggregate of active subjects and forces acting beyond the company and influencing the establishment possibilities to establish and maintain the 
successful cooperation relations with target customers. On the one part, each interested party has milestones and the KPI system characterizing the results being achieved. On the other part, it happens very often that the milestones and the achievement results indicators in various stakeholders have a strong dependence. For example, the percentage of return of customers (loyal guests) directly depends both on the quality of the organization business processes implementation and on the aggregate of external estimates by supervisory bodies or restaurant critics.

Another direction of the intersector interaction of food service stakeholders is the coordination of efforts on changing social standards, individual behavior and branch practices, aimed at the achievement of public deliverables, e.g., in the sphere of creating conditions for healthier food selection in terms of national fight against obesity and other alimentary-dependant diseases [6-8], prevention of ecological risks and provision of ecological stability [9], grows of the quality of services based on the assessment of the level of professional ethics training [10-12].

The instrument being developed in the paper can create a basis for quantitative assessment of the empirical correlation between the quality of the company services, its relations with the interested parties and the stock value parameters. For example, according to the study of assessment of the impact of the interested parties' relation, on the corporate production, a quantitative research method was developed and tried out that allowed revealing the inner price of the relations stock. However, the modern market has no such instrumentation for systemic data collection and forming such assessment as, for example, (a) trust; (b) satisfaction; (c) consensus; and (d) commitment [13].

For developing the uniform system of criteria for catering establishments assessment, various approaches to their classification have been analyzed. For example, in particular, in [14], special attention is paid to such criteria as "food, service, and ambience", in [15-17], criteria "food, service, ambience, deals/discounts and worthiness", and in [18], "food, service, price, ambiance, anecdotes, and miscellaneous". The paper [19] offers the multi-aspect ranking o restaurants in criteria "food, service, ambience, value, and overall experience" based on the good grief algorithm use.

The goal of this work is developing an information search system enabling to carry out a search of a catering establishment under regulator criteria of assessment for various groups of interested parties (consumers, business owners, sanitary inspectors, state management authorities, catering establishment critics, etc.).

For achieving the set goals and their implementation, the set of common and special methods was used: dialectic cognition method for the company development concept specification; system approach, historical approach, methods of economical and statistic analysis, examination and compilation for the analysis of development dynamics and factors conditioning the transformation of the food industry market; methods of systemic and structural analysis, induction and deduction, abstraction and analogy, in order to demonstrate interrelation of criteria of assessing the activity and the strategy of food industry development, used by stakeholders; methods of operative and strategic analysis to assess the possibility of adaptation of the existing modern systems of assessment aggregation to the needs of various groups of stakeholders.

\section{RESEARCH RESULTS}

For the development, offered in the information search system paper, the terms of reference were prepared with regard of the requirements given in [20-23].

While writing the terms of reference, it was taken into account that the information search system being developed belongs to the first category in terms of degree of the development novelty and the group of complexity of the task being solved, i.e., has individual characteristics and provides for the development of algorithms for solving ultimate planning tasks and the multi-factor analysis.

The terms of reference developed contains the following sections:

1. Information search system name and field of application.

2. Development destination. The section contains the characteristic of functional, operational destination of the information search system, and the users characteristic.

3. Technical requirements to the information search system. The section contains requirements to functional characteristics, database logical structure, usability, efficiency, operation conditions, software compatibility, user interface, hardware, software, and interaction.

While writing the terms of reference, it was taken into account that the system should allow carrying out the multi-factor filtering and assessment of catering establishments with regard of interests of various groups of users (consumers, business owners, catering establishment critics). The list of criteria and criteria and the rating scale of information search system being developed is given below:

1. Analysis and ranking of catering establishments according to consumers is carried out on a scale from one to five and the following criteria: range of meals and drinks, meals assessment, average bill, entertainment, service, cleanness, convenience, additional services. Table 1 gives the components of the criterion "Range of foods and drinks" with their classification by scale. 
Table 1 Criterion "Range of foods and drinks"

\begin{tabular}{|c|c|c|c|c|c|}
\hline \multirow{2}{*}{ Criterion } & \multicolumn{5}{|c|}{ Assessment scale } \\
\hline & 1 & 2 & 3 & 4 & 5 \\
\hline Food to go & Absent & & limited stock & & present \\
\hline Meals waiting time & $\begin{array}{c}36 \text { and more } \\
\text { minutes }\end{array}$ & 26-35 minutes & $16-25$ minutes & $8-15$ minutes & to 7 minutes \\
\hline $\begin{array}{l}\text { Degree of the consumer's } \\
\text { participation in the service } \\
\text { process }\end{array}$ & & & Mixed access & Limited access & Free access \\
\hline Product range & & Limited & Narrow & Specialized & Wide \\
\hline Children's menu availability & Absent & & & & \\
\hline Wine list & Absent & to 5 positions & to 10 positions & to 15 positions & $\begin{array}{c}\text { more than } 15 \\
\text { positions }\end{array}$ \\
\hline Business lunch & Absent & & & & present \\
\hline
\end{tabular}

2. The assessment from the restaurant critic's point of view is carried out under the following criteria:

- the restaurant environment that is assessed under the following indicators: atmosphere, cleanness, children's room, cloakroom, serving, design, music, the restaurant location, restrooms, table booking;

- $\quad$ servic, the maximal and minimal indicators of which are given in Table 2;

- quality, the assessment is made under the following indicators: food quality, quality of the meals design;

- menu, the assessment is made under the parameters: wine list completeness, price and quality ratio, meals in stock (variety), information about the meal, menu design;

Table 2 Criterion "Service"
- safety assessment is carried out under the following indicators: food safety, evacuation procedure (escape plan), interior safety, video observation.

3. At the analysis from the point of view of business owners, the assessment is carried out under the internal and external parameters, External assessment criteria include: price policy, location, target audience, staff qualification, atmosphere, menu, dishes, availability of initial table layout (for restaurants), condition of main funds, cleanness, meals/presentation.

\begin{tabular}{|l|l|l|}
\hline \multicolumn{1}{|c|}{ Criterion tracked } & \multicolumn{1}{|c|}{ 1 level assessment } & \multicolumn{1}{c|}{ 5 level assessment } \\
\hline $\begin{array}{l}\text { Staff time management } \\
\text { skills }\end{array}$ & $\begin{array}{l}\text { The employee is distracted, unorganized; } \\
\text { his/her speech lacks confidence. }\end{array}$ & $\begin{array}{l}\text { The employee speaks confidently, and } \\
\text { performs all the actions strictly. }\end{array}$ \\
\hline Individual approach & $\begin{array}{l}\text { The employee communicates as a "robot", and } \\
\text { it is obvious that this job is of no interest and } \\
\text { importance to him/her. }\end{array}$ & $\begin{array}{l}\text { The employee treats every guest in a different } \\
\text { way. Actually tries to find approach to every } \\
\text { guest and to satisfy his/her needs. }\end{array}$ \\
\hline Appearance standard & $\begin{array}{l}\text { The employees don't have any uniform or } \\
\text { badges. Clothes are out of press, with spots. }\end{array}$ & $\begin{array}{l}\text { All employees have neat clothes, their } \\
\text { uniform has a single standard and is ironed. }\end{array}$ \\
\hline Smile/greeting & $\begin{array}{l}\text { No smile, the employee is not interested in a } \\
\text { guest. }\end{array}$ & $\begin{array}{l}\text { The smile is natural, it is obvious that the } \\
\text { guest is welcome here. }\end{array}$ \\
\hline $\begin{array}{l}\text { Knowledge of meals } \\
\text { composition }\end{array}$ & $\begin{array}{l}\text { The employee is confused about the meals } \\
\text { composition, and doesn't know elementary } \\
\text { differences in meals. }\end{array}$ & $\begin{array}{l}\text { The employee tells about every meal, and } \\
\text { selects the meal up to your taste. }\end{array}$ \\
\hline Order execution time & $\begin{array}{l}\text { According to the regulations, the order was } \\
\text { delivered late, no excuses were given. }\end{array}$ & $\begin{array}{l}\text { The order was delivered earlier than } \\
\text { scheduled. }\end{array}$ \\
\hline
\end{tabular}


Inner assessment criteria include:

- work of the service staff, the maximal and minimal indicators of which are given in Table 3;

- $\quad$ managing staff work efficiency that is assessed under the following indicators: understanding the establishment goals (their tasks), adaptation to the specific situation, creation of conditions encouraging the employees to perform their work efficiently in accordance with their obligations, checking feedback and recommendations from guests, process of delivering the decisions from the manager to his employees, presence of sanitary record cards in all service staff, kitchen workers and cleaning employees, basic computer user skills (Microsoft Excel, Word), depending on the system used, control of the sufficient available amount of resources for work, preparation of the efficient staff working schedule, with regard of wishes of staff, knowledge of document circulation at the enterprise, knowledge of business communication ethics and negotiation skills;
- general team condition. Corporate culture and interaction of employees, assessed under the following indicators: all employees understand the company goals and act according to these goals; communication between the employees, absence of conflicts; open discussion of problems that arose in the team, and discussion of work optimization offers.

Increasing the quality of analytical information required for making managerial decisions aimed at the achievement of the company [24] strategic goals is possible based on the allocation of sources of information used for analysis; development and approval of the polic of access to record and analytical data contained in the systems; marging out factors that can impact the information received from record and analytical systems [25].

When aggregating various assessment criteria, a need arises to determine their value for various groups of stakeholders and assessing the possibility of forming integral indicators on their basis, and tools of analytical data assessment, allowing ranking of catering establishments based on different target tasks and contribution to the achievement of public deliverables.

Table 3 Criterion "Service staff work"

\begin{tabular}{|c|c|c|}
\hline Criterion assessed & Minimal assessment point is 1 & Maximal assessment point is 5 \\
\hline $\begin{array}{l}\text { 1.Task fulfillment in terms of the } \\
\text { work shift }\end{array}$ & $\begin{array}{l}\text { The staff goes beyond the limits of working } \\
\text { hours. Some tasks are not completed. }\end{array}$ & $\begin{array}{l}\text { The employees complete the shift plan } \\
\text { fully. All tasks are completed. }\end{array}$ \\
\hline 2.Preparation to the current work. & $\begin{array}{l}\text { By the day of opening, the company is not } \\
\text { ready to provide service to guests. }\end{array}$ & $\begin{array}{l}\text { Preparation to opening is completed in } \\
\text { advance. The company is ready to } \\
\text { operate and to provide services to the } \\
\text { customers. }\end{array}$ \\
\hline $\begin{array}{l}\text { 3. Politeness of the service staff and } \\
\text { good attitude to guests }\end{array}$ & $\begin{array}{l}\text { No good attitude to guests, lack of politeness. } \\
\text { In the worst case, low conduct and aggression. }\end{array}$ & $\begin{array}{l}\text { The staff is welcoming and smiling. It } \\
\text { is always possible to find approach to } \\
\text { any restaurant guest. }\end{array}$ \\
\hline 4. Practical knowledge of the service & $\begin{array}{l}\text { The employee has no knowledge of the service } \\
\text { operation. }\end{array}$ & $\begin{array}{l}\text { The experienced employee who } \\
\text { knows the service on practice. }\end{array}$ \\
\hline $\begin{array}{l}\text { 5. Knowledge of the menu and the } \\
\text { meals composition, the internal } \\
\text { standards, and the charging and } \\
\text { stimulation system. }\end{array}$ & $\begin{array}{l}\text { The employee lacks the menu knowledge, is } \\
\text { confused about names and meal ingredients. } \\
\text { The employee is not familiar with the internal } \\
\text { standards system. }\end{array}$ & $\begin{array}{l}\text { At the employment, the employer } \\
\text { should have the full knowledge of the } \\
\text { menu and the meals composition, the } \\
\text { internal standards, and the charging } \\
\text { and stimulation system. }\end{array}$ \\
\hline $\begin{array}{l}\text { 6. Desire to improve himself/herself, } \\
\text { gain new skills, attending mater } \\
\text { classes and trainings. }\end{array}$ & $\begin{array}{l}\text { The employee has no interests beside the tasks } \\
\text { set. }\end{array}$ & $\begin{array}{l}\text { Attending various } \\
\text { trainings and classes, } \\
\text { workshops, active participation in } \\
\text { team projects. }\end{array}$ \\
\hline $\begin{array}{l}\text { 7. Acting strictly in accordance with } \\
\text { the company standards but, in extreme } \\
\text { cases, skill to undertake responsibility }\end{array}$ & $\begin{array}{l}\text { Full or partial neglecting the company } \\
\text { standards. The employee knows better what } \\
\text { and how to do. }\end{array}$ & $\begin{array}{l}\text { Knowledge of standards and } \\
\text { following them, together with } \\
\text { moderate proactivity in terms of these } \\
\text { standards }\end{array}$ \\
\hline
\end{tabular}


[6] O. Barata-Cavalcanti, D. Ty, W. Novelli, S. Costa, T.T.K. Huang, Informing a roadmap for crosssectoral collaboration on portion size management as a national strategy to improve population nutrition - a Delphi study, Obesity Science and Practice, WileyBlackwell, 2019, pp. 189-202. DOI: 10.1002/osp4.331

[7] L.M. Bogart, G. Castro, D.A. Cohen, A qualitative exploration of parents', youths' and food establishment managers' perceptions of beverage industry self-regulation for obesity prevention, Public Health Nutrition, Cambridge University Press, 2019, pp. 805-813. DOI: 10.1017/S1368980018003865

[8] M. Sigala, A market approach to social value co-creation: Findings and implications from "Mageires" the social Restaurant, Marketing Theory, SAGE Publications Ltd, 2018, pp. 27-45. DOI: $10.1177 / 1470593118772208$

[9] Y. J. Jang, T. Zheng, R. Bosselman, Top managers' environmental values, leadership, and stakeholder engagement in promoting environmental sustainability in the restaurant industry, International Journal of Hospitality Management, 2017, pp. 101-111. DOI: 10.1016/j.ijhm.2017.03.005

[10] C.S. Deale, S.-H. Lee, An Exploratory Study of Hospitality and Tourism Stakeholders' Perceptions of Professional Etiquette, Journal of Hospitality and Tourism Education, Routledge, 2019, pp 89-99. DOI: 10.1080/10963758.2019.1654891

[11] T. Shimmura, T. Nonaka, T. Yamamoto, K. Arai, Introducing Batch Production and Training Game for Enhancing Both Quality of Dish and Labor Productivity at Japanese Cuisine Restaurant in: R.Teti (Eds.), Procedia CIRP, 2019, pp. 690-694. DOI: 10.1016/j.procir.2019.02.034

[12] C.S. Deale, S.-H. Lee, An Exploratory Study of Hospitality and Tourism Stakeholders' Perceptions of Professional Etiquette, Journal of Hospitality and Tourism Education, 2019, pp. 107-112. DOI: 10.1080/10963758.2019.1654891

[13] D. J. Finch, The Stakeholder Scorecard: Evaluating the Influence of Stakeholder Relationships on Corporate Performance 358 Publisher Proquest, Umi Dissertation Publishing Publication City/Country Charleston SC, United States, 2011, 358 p.

[14] B. Lu, M. Ott, C. Cardie, B.K. Tsou, Multiaspect sentiment analysis with topic models, IEEE, 
Canada, 2011, pp. 81-82. DOI: 10.1109/ICDMW.2011.125

[15] A. Gupta, T. Tenneti, A. Gupta, Sentiment based Summarization of Restaurant Reviews, Final Year Project, 2009, $11 \quad$ p. https://pdfs.semanticscholar.org/da73/63c004cd28f8f3c 423cc9a0a286d492eb904.pdf

[16] N. Mittal, B. Agarwal, S. Laddha, M. Sharma, Aspect Based Analysis for Rating Prediction of the Restaurant Reviews, International Journal of Computer Systems, 2015, pp. 59-62. DOI: $10.1145 / 3078714.3078737$

[17] M. Govindarajan, Sentiment Analysis of Restaurant Reviews using Hybrid Classification Method, International Journal of Soft Computing and Artificial Intelligence, 2014, pp. 17-23. DOI:10.4018/978-1-5225-1022-2.ch003

[18] G. Ganu, N. Elhadad, A. Marian, Beyond the Stars: Improving Rating Predictions using Review Text Content, 12th International Workshop on the Web and Databases, 2009, pp.1-6. DOI:10.1002/asi.21462

[19] B. Snyder, R. Barzilay, Multiple aspect ranking using the good grief algorithm, Joint Human Language Technology: North American Chapter of the ACL, 2007, pp. 300-307.

[20] GOST 19.201-78 Yedinaya sistema programmnoy dokumentatsii. Tekhnicheskoye zadaniye. Trebovaniya k soderzhaniyu i oformleniyu. M.: Izdatel'stvo standartov, 1990. 4 s.

[21] 830-1998. IEEE Recommended Practice for Software Requirements Specifications. Available at: http://www.math.uaa.alaska.edu/ afkjm/cs401/IEEE83 $0 . p d f$

[22] ISO/IEC/ IEEE 29148-2018 Systems and software engineering. Life cycle processes.Requirements engineering. Available at: https://www.iso.org/ru/standard/72089.html

[23] GOST $\mathrm{R}$ ISO/MEK 9126-93. Informatsionnaya tekhnologiya. Otsenka programmnoy produktsii. Kharakteristiki kachestva i rukovodstva po ikh primeneniyu. - M.: Gosstandart Rossii, 2004. 13 s.

[24] M. Garbowski, S. Drobyazko, V. Matveeva, O. Kyiashko, V. Dmytrovska, Financial Accounting of EBusiness Enterprises. Academy of Accounting and Financial Studies Journal, 2019, 85-99. DOI:10.1007/978-3-319-68762-9_16 145.
[25] D. Xia, Q.Yu, Q. Gao, G. Cheng, Sustainable technology selection decision-making model for enterprise in supply chain: Based on a modified strategic balanced scorecard, Journal of cleaner production, 2017, pp.1337-1348. DOI: 10.1016/j.jclepro.2016.09.083 